\title{
Disseminated neoplasia and large foci indicating heavy haemocytic infiltration in cockles Cerastoderma edule from Galicia (NW Spain)
}

\author{
Antonio Villalba*, María J. Carballal, Carmen López \\ Centro de Investigacións Mariñas, Consellería de Pesca, Marisqueo e Acuicultura, Xunta de Galicia, Aptdo. 13, \\ 36620 Vilanova de Arousa, Spain
}

\begin{abstract}
A histopathological survey was performed to search for the cause of high mortality in the cockle Cerastoderma edule in northern rías of Galicia (northwestern Spain). From limited sampling, 2 severe pathological conditions with high prevalence were found: disseminated neoplasia and the occurrence of numerous, large foci of heavy haemocytic infiltration. Both conditions were detected in areas affected by high mortality and were absent (foci of haemocytic infiltration) or with lower prevalence (disseminated neoplasia) in an area with unnoticeable mortality that was chosen as a reference. Advanced cases of both pathological conditions were associated with extensive tissue destruction. Because of the severity of the lesions and their high prevalence, both pathological conditions could have contributed to the high mortality.
\end{abstract}

KEY WORDS: Cerastoderma edule $\cdot$ Disseminated neoplasia $\cdot$ Inflammation

\section{INTRODUCTION}

High mortality of cockles in exploited intertidal beds in northern rías of Galicia (northwestern Spain) was reported by fishermen in 1997. A histopathological survey was performed to search for possible causes of the mortality. As a result, 2 severe pathological conditions with high prevalence were found: disseminated neoplasia and the occurrence of numerous, large foci indicating heavy haemocytic infiltration.

Epizootiological outbreaks of disseminated neoplasia have been reported in association with mass mortalities of various bivalve species (see reviews by Peters 1988, Elston et al. 1992). In cockles, disseminated neoplasia was described in Cerastoderma edule from Ireland and Brittany (France) (Twomey \& Mulcahy 1984, 1988a, Poder \& Auffret 1986). A single case of disseminated neoplasia was reported in Cerastoderma glaucum from Galicia (Rodríguez et al. 1997).

*E-mail: villalba@cimacoron.org
Other bivalve species were found to be affected by disseminated neoplasia in this region (Alderman et al. 1977, Gutiérrez et al. 1986, Villalba et al. 1995).

Both pathological conditions and their implications for cockle mortality are described.

\section{MATERIALS AND METHODS}

By visual inspection, a number higher than usual of empty cockle shells was observed above the sediment of beds affected by mortality. Many of the empty shells had the 2 valves joined by a still elastic ligament, which is usually a sign of recent death. Unfortunately, mortality rate was not estimated. Five samples of 25 buried cockles were taken from intertidal beds. The first sample was taken from a bed affected by mass mortality in Ría do Barqueiro (inner side) in April 1997. After detection of lesions involving large foci indicating haemocytic infiltration in that sample, a second sample was taken at the same place in June 1997. Subsequently, samples were taken from the 2 flanking 
rías, also affected by mortality (Ría de Ortigueira and Ría de Viveiro), and from a bed not affected by mortality (port of Vicedo, on the outer side of the Ría do Barqueiro), chosen as a reference, in July 1997. The locations of the sampling sites are shown in Fig. 1.

Sampled cockles were shucked, and an entire gill lamella was excised and incubated in fluid thioglycollate medium (FTM) to detect parasites of the genus Perkinsus (Ray 1966). In addition, an approximately $5 \mathrm{~mm}$ thick section of tissue, containing gills, visceral mass, foot and mantle lobes, was fixed in Davidson's solution and embedded in paraffin. Sections of $5 \mu \mathrm{m}$ thickness were stained with Harris' haematoxylin and eosin (H\&E) (Howard \& Smith 1983). Histological sections were examined under a light microscope for the presence of pathological conditions.

\section{RESULTS}

No sign of Perkinsus-like parasitisation was detected in tissues that had been incubated in FTM. Examination of the histological sections disclosed 2 severe pathological conditions: disseminated neoplasia and the occurrence of numerous, large foci indicating heavy haemocytic infiltration. Disseminated neoplasia were characterised by infiltration of the connective tissue of various organs by abnormal cells with a high nucleus/cytoplasm ratio (Figs 2 to 5). These cells were round to oval in shape and $6.4 \pm 0.2 \mu \mathrm{m}$ (mean $\pm \mathrm{SE}, \mathrm{n}=50$ ) in diameter. Nuclei were round or pleomorphic, $4.5 \pm 0.2 \mu \mathrm{m}$ (mean $\pm \mathrm{SE}, \mathrm{n}=50$ ) in length, had a diffuse chromatin pattern and possessed up to 2 nucleoli. Abnormal cells in mitotic process were frequently observed (Fig. 5). Various stages of disease progression were detected, from a few scattered abnormal cells to heavy infiltration throughout all the organs involving loss of the normal architecture of tissues and organs.

The other pathological condition was characterised by heavy haemocytic infiltration giving rise to numerous, large, dense masses of haemocytes in various organs (gill, gonad, digestive gland, kidney, heart and

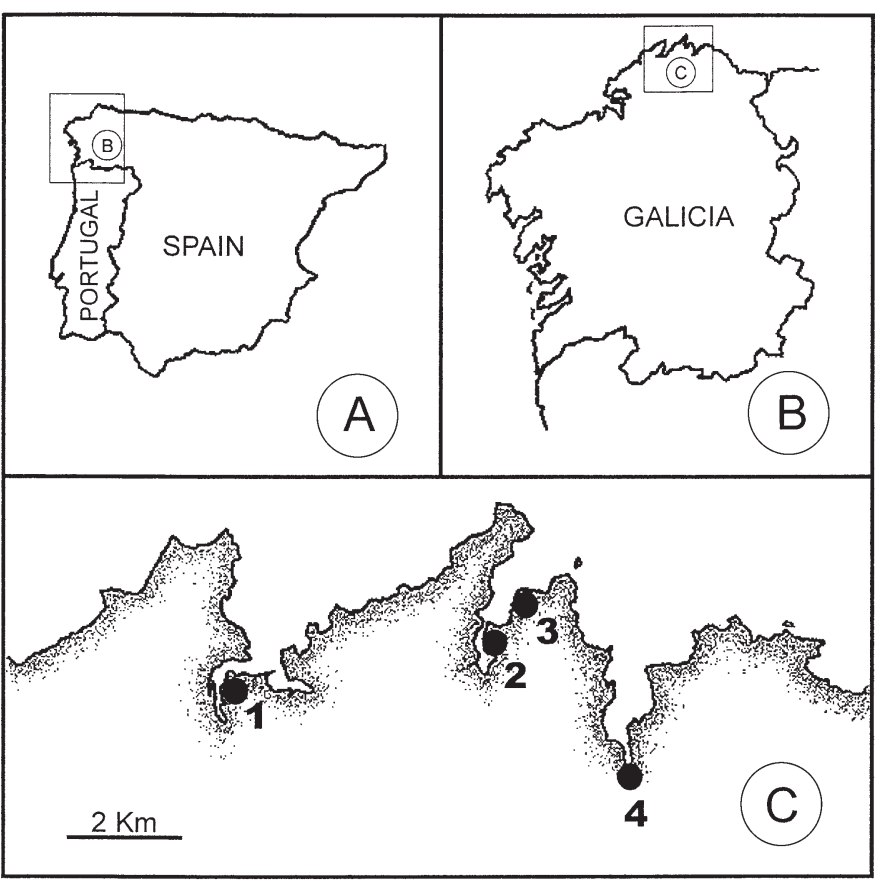

Fig. 1. Map of the study area showing locations of sample points. 1: Ría de Ortigueira; 2: Ría do Barqueiro; 3: Port of Vicedo; 4: Ría de Viveiro

foot). These inflammatory foci involved loss of the normal architecture and extensive destruction of tissues and organs (Fig. 6). Unidentified cells (UC) were observed within haemocytes occurring in the inflammatory foci and in blood vessels. Up to 4 of these UCs in a single haemocyte were observed. UCs appeared with variable outlines, spherical to elongated, and ranged 2 to $5 \mu \mathrm{m}$ in length (Fig 7). Light microscopy did not allow a detailed observation of UC morphology due to their small size. Nevertheless, their shapes differed, some appearing uninucleated and others multinucleated (up to 3 nuclei).

Table 1 shows the prevalence of each condition in the samples. The prevalence of large inflammatory foci was high in every sample but absent in that from the port of Vicedo, the bed not affected by mortality. Cases of disseminated neoplasia were found at every collection site, although the prevalence was much lower in

Figs 2 to 5. Disseminated neoplasia in Cerastoderma edule. Fig. 2. Histological section through the gills, showing heavy infiltration of the connective tissue by neoplastic cells. (H\&E, 115 $)$. Fig. 3. Histological section through the kidney, showing heavy infiltration of the connective tissue by neoplastic cells. (H\&E, 225×). Fig. 4. Histological section through the gonad, showing heavy infiltration of the connective tissue by neoplastic cells. (H\&E, $4 \overline{50 \times)}$. Fig. 5. High magnification of a histological section showing neoplastic cells, some in mitotic process (arrows). (H\&E, 1125x). Figs 6 \& 7. Large foci of heavy haemocytic infiltration in Cerastoderma edule. Fig. 6. Histological section, showing various large, dense masses of haemocytes ( $)$ in an area close to the foot. (H\&E, 50×). Fig. 7. Histological section through an area heavily infiltrated by haemocytes. Unidentified cells (arrows) can be seen within haemocytes. (H\&E, 1100×) 

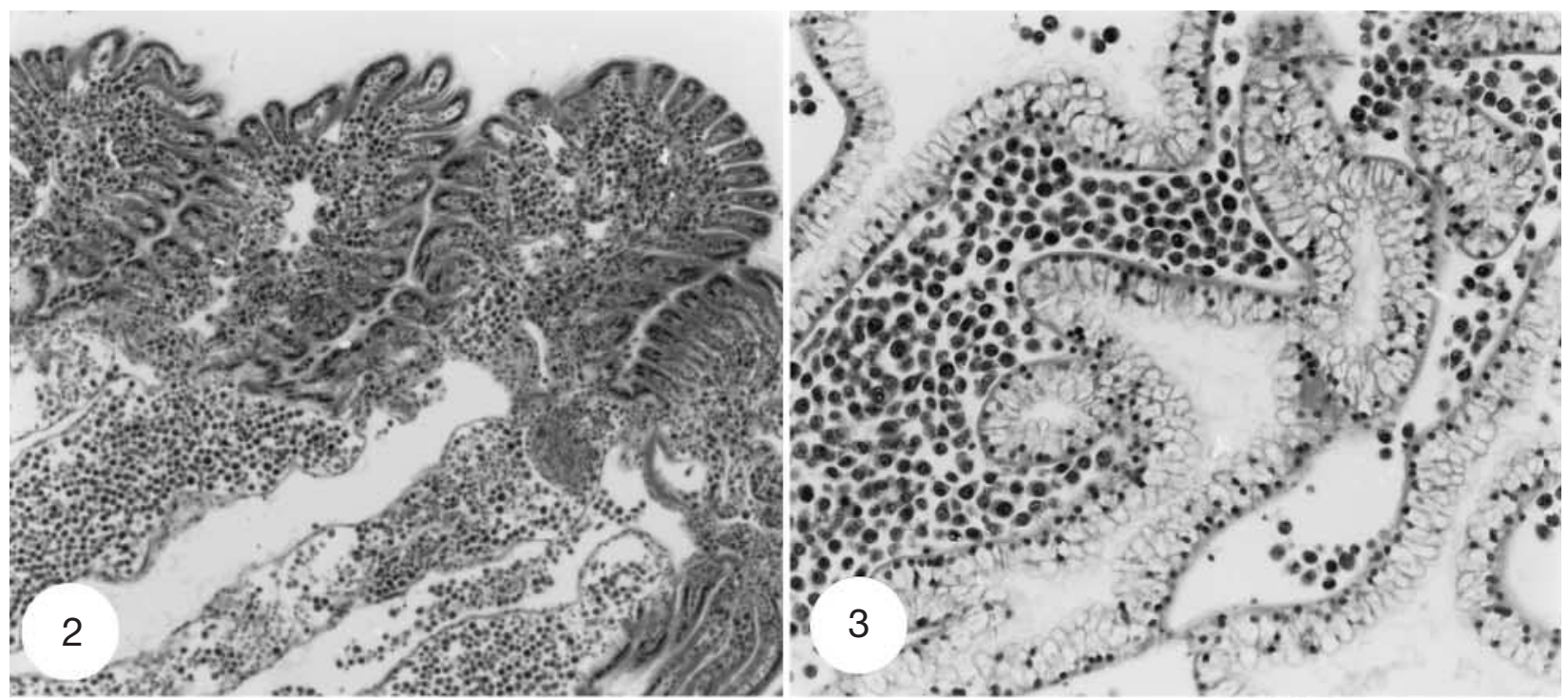

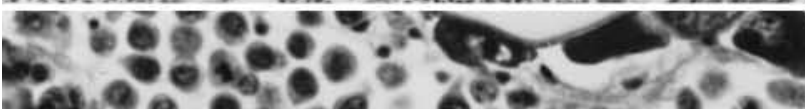

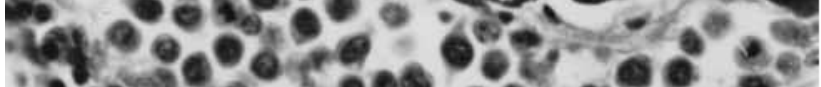

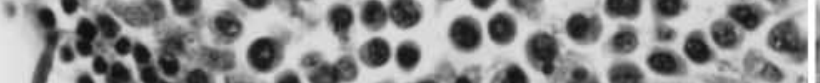

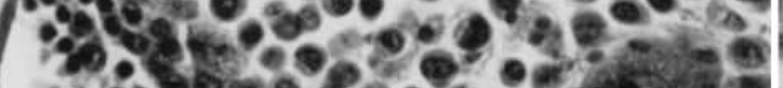

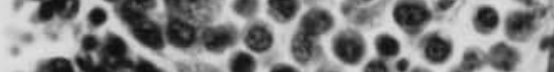

i.

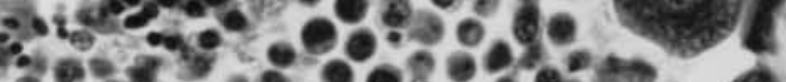

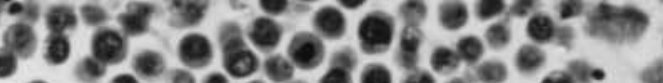

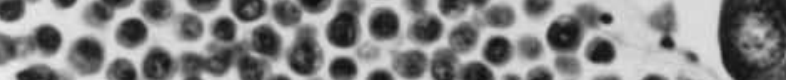

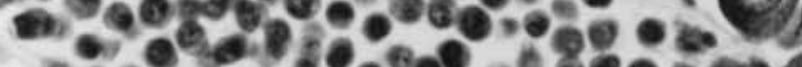

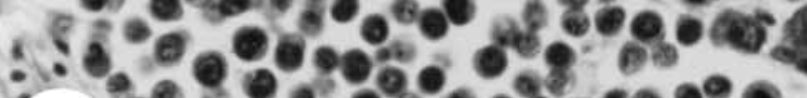

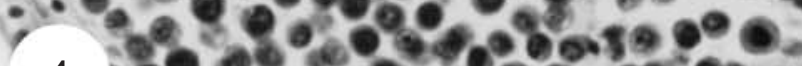

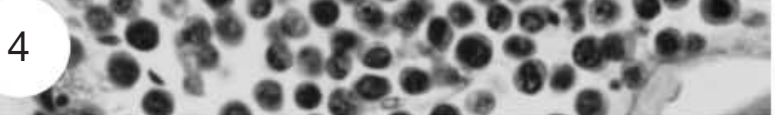

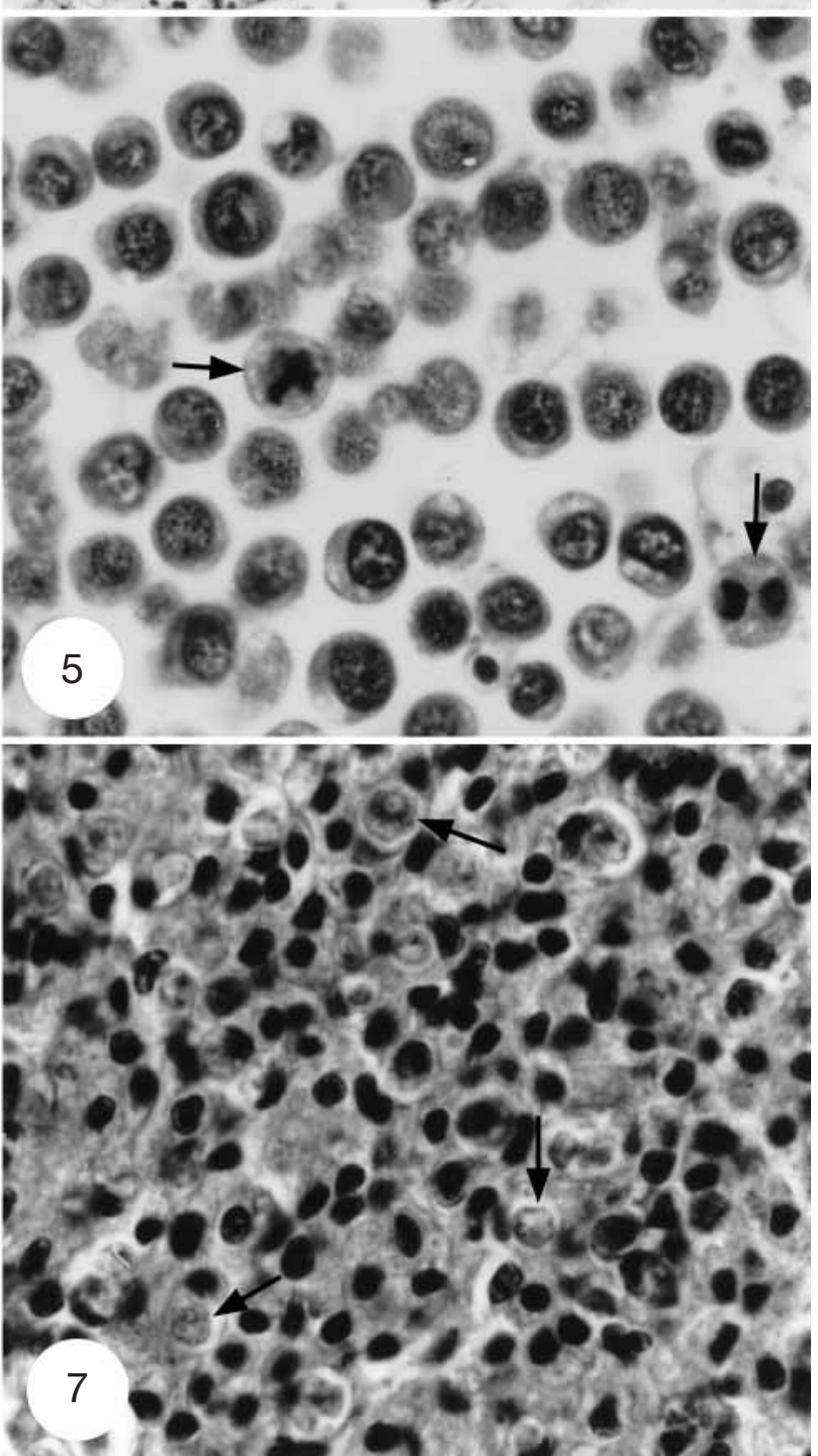


Table 1. Prevalence of disseminated neoplasia and occurrence of large foci simultaneously by both pathological conditions in every sample of Cerastoderma edule

\begin{tabular}{|lcccc|}
\hline Sampling site & $\begin{array}{c}\text { Date } \\
(1997)\end{array}$ & $\begin{array}{c}\text { Disseminated } \\
\text { neoplasia (\%) }\end{array}$ & $\begin{array}{c}\text { Inflammatory } \\
\text { foci (\%) }\end{array}$ & $\begin{array}{c}\text { Both con- } \\
\text { ditions (\%) }\end{array}$ \\
\hline Ría do Barqueiro & April & 0 & 75 & 0 \\
Ría do Barqueiro & June & 60 & 88 & 52 \\
Ría de Ortigueira & June & 27 & 73 & 27 \\
Ría de Viveiro & June & 84 & 64 & 56 \\
Port of Vicedo & July & 4 & 0 & 0 \\
\hline
\end{tabular}
indicating heavy haemocytic infiltration, and percentage of cockles affected

research program is being developed in our laboratory to obtain information on both conditions and their effects on the cockle industry of Galicia.

\begin{abstract}
Acknowledgements. Olga Teijeiro and Daniel Cerveira, biologists of the Delegación Territorial da Consellería de Pesca, Marisqueo e Acuicultura da Xunta de Galicia in Celeiro, provided information on the occurrence of mortality and location of beds affected and not affected by mortality, and they were very helpful in obtaining samples.
\end{abstract}

\section{LITERATURE CITED}

the port of Vicedo. In Ría do Barqueiro, the neoplastic condition was only found in the second sampling.

\section{DISCUSSION}

The search for causes of high mortality in the cockle Cerastoderma edule in northern rías of Galicia disclosed the occurrence of 2 severe pathological conditions with epizootic levels. Morphological (Twomey \& Mulcahy 1984, Auffret \& Poder 1986, Poder \& Auffret 1986), epizootiological (Twomey \& Mulcahy 1988a) and transmission (Twomey \& Mulcahy 1988b) aspects of disseminated neoplasia in populations of the cockle C. edule from Ireland and France have been described. Morphological aspects of the disseminated neoplasia found in this study are similar to those described in the previously cited papers. Therefore, it appears that an epizootic is widespread throughout the European Atlantic coast. Collins (1998) has confirmed that this epizootic is still present on the Irish coast and suggested a viral aetiology after transmission experiments. Epizootics of disseminated neoplasia have been described associated with mass mortalities of other bivalve species (Peters 1988, Elston et al. 1992).

UCs were previously reported as a protistan parasite termed 'cockle parasite X' (López et al. 1998). However, ultrastructural study of UCs is required to disclose whether they are parasites or phagocytosed cockle cells. This may help to elucidate the cause of the heavy inflammatory reaction giving rise to the large haemocytic foci.

Both pathological conditions occurred with high prevalence in the areas affected by mortality and were absent (large inflammatory foci) or had a low prevalence (disseminated neoplasia) in the non-affected area. Both pathological conditions caused severe lesions in cockles. These data may suggest an association of the occurrence of the 2 lesions with cockle mortality. However, the absence of cases of disseminated neoplasia in the first sample from Ría do Barqueiro makes it difficult to support such an association. A
Alderman DJ, Van Banning P, Pérez-Colomer A (1977) Two European oyster (Ostrea edulis) mortalities associated with abnormal haemocytic condition. Aquaculture 10: $335-340$

Auffret M, Poder M (1986) Sarcomatous lesion in the cockle Cerastoderma edule. II. Electron microscopical study. Aquaculture 58:9-15

Collins C (1998) Studies on a neoplasm of the cockle, Cerastoderma edule (Linnaeus). PhD thesis dissertation. National University of Ireland, Cork

Elston RA, Moore JD, Brooks K (1992) Disseminated neoplasia of bivalve molluscs. Rev Aquat Sci 6:405-466

Gutiérrez M, Sarasquete MC (1986) Un caso de hemocitosarcoma hialino en el mejillón, Mytilus edulis L. (Pelecipoda: Mytilidae) de la costa NO. de España. Invest Pesq 50: $265-269$

Howard AW, Smith CS (1983) Histological techniques for NMFS-F/NEC-25, Woods Hole

López C, Villaba A, Carballal MJ, Corral L, Azevedo C (1998) Mass mortalities of cockles, Cerastoderma edule, in Galicia (NW Spain) associated with a disseminated neoplasia and an unidentified protistan parasite. 3rd International Symposium on Aquatic Animal Health, 1998, Baltimore

Peters E (1988) Recent investigations on the disseminated sarcomas of marine bivalve molluscs. Am Fish Soc Spec Publ 18:74-92

Poder M, Auffret M (1986) Sarcomatous lesion in the cockle Cerastoderma edule. I. Morphology and population survey in Brittany, France. Aquaculture 58:1-8

Ray SM (1966) A review of the culture method for detecting Dermocystidium marinum, with suggested modifications and precautions. Proc Natl Shellfish Assoc 54:55-69

Rodríguez H, Soto M, Arias C, Estévez J (1997) A case of disseminated haemic sarcoma in Cerastoderma (=Cardium) glaucum Poiret, 1789 collected from Ría de Vigo (NW Spain). Bull Eur Assoc Fish Pathol 17:88-90

Twomey E, Mulcahy MF (1984) A proliferative disorder of possible haemic origin in the common cockle, Cerastoderma edule. J Invertebr Pathol 44:109-111

Twomey E, Mulcahy MF (1988a) Epizootiological aspects of a sarcoma in the cockle Cerastoderma edule. Dis Aquat Org $5: 225-238$

Twomey E, Mulcahy MF (1988b) Transmission of a sarcoma in the cockle Cerastoderma edule (Bivalvia; Mollusca) using cell transplants. Dev Comp Immunol 12:549-559

Villalba A, Peters EC, López MC, Carballal MJ (1995) Disseminated sarcoma in the clam Ruditapes decussatus in Galicia (NW Spain). J Invertebr Pathol 65:76-78 marine bivalve mollusks. NOAA Technical Memorandum 